\title{
The search for seismic signatures of movement at the glacier bed in a polythermal valley glacier
}

\author{
Joseph POMEROY, ${ }^{1}$ Alex BRISBOURNE, ${ }^{2}$ Jeffrey EVANS, ${ }^{1}$ David GRAHAM ${ }^{1}$ \\ ${ }^{1}$ Polar and Alpine Research Centre, Department of Geography, Loughborough University, Loughborough, UK \\ E-mail: d.j.graham@lboro.ac.uk \\ ${ }^{2}$ British Antarctic Survey, Natural Environment Research Council, Cambridge, UK
}

\begin{abstract}
A passive seismology experiment was conducted across the main overdeepening of Storglaciären in the Tarfala valley, northern Sweden, to investigate the spatial and temporal distribution of basal microseismic waveforms in relation to known dynamics of this small polythermal sub-arctic glacier. The high ablation rate made it difficult to keep geophones buried and well coupled to the glacier during the experiment and reduced the number of days of good-quality data collection. The characterization of typical and atypical waveforms showed that the dominant waveforms were from near-surface events such as crevassing. Waveforms resembling basal microseismic signals were very rare, and seldom observed on more than two seismic stations simultaneously. The analysis of waveforms, amplitudes and particle motions suggested a near-field origin for most events. Even though basal sliding is known to occur in the overdeepening, no convincing examples of basal waveforms were detected, suggesting basal microseismic signals are rare or difficult to detect beneath polythermal glaciers like Storglaciären. We discuss the reasons for failing to locate basal signals, consider the origin of common waveforms and make recommendations for setting up passive seismology experiments on glaciers with high ablation rates.
\end{abstract}

\section{INTRODUCTION}

Subglacial processes such as basal sliding exert a strong control on glacier flow, so any understanding of glacier dynamics requires consideration of subglacial hydrology, soft-bed rheology and the strength of coupling between the glacier and its bed (Fischer and others, 1996). For example, the soft-bed deformation model shows how glaciers overriding soft, water-saturated beds can impart sufficient shear stress to initiate deep, widespread and pervasive deformation which makes a significant contribution to the forward motion of the glacier (Boulton and Hindmarsh, 1987). The soft-bed deformation model has been used to explain fast flow in ice streams (Blankenship and others, 1986; Alley and others, 1987; Boulton and Hindmarsh, 1987; Boulton and others, 2001), glacier surges (Fischer and Clarke, 2001), and binge-purge cycles in palaeo-ice sheets leading to Heinrich events and abrupt climate change (MacAyeal, 1993; Clark, 1994). However, the applicability of the softbed deformation model is highly contested. The competing ice-bed mosaic model characterizes subglacial deformation as a discrete, depth-limited, cumulative and time-transgressive process. In this model, sticky spots (areas of high basal drag) and basal sliding are more important controls on glacier flow than deformation (Piotrowski and others, 2001, 2004; Thomason and Iverson, 2009). It is important to resolve the uncertainties regarding subglacial processes, as a better understanding of the subglacial environment is required to parameterize ice-sheet models, to predict glacio-dynamic response to climate change and to match modelled glacier dynamics to sediment-landform associations (Carr, 2004; Boulton and Hagdorn, 2006; Solomon and others, 2007; Passchier and others, 2010).

The inaccessibility of the subglacial environment makes direct observations of subglacial processes difficult; borehole investigations and observations in glacial tunnels may provide valuable insights, but they only provide a snapshot of a spatially limited part of the glacier bed (Clarke, 2005). By contrast, passive seismology offers a potential means of indirectly observing subglacial processes at a high temporal resolution, over a relatively wide area and over a period of several days or weeks (Roux and others, 2008). Passive seismology experiments can be designed to detect natural microseismic events within a few kilometres of their source.

A variety of glacial processes are thought to generate microseismic signals through the brittle failure of ice and the release of elastic strain energy, with up to tens of events per minute being recorded and a wide variety of waveforms produced (West and others, 2010). In addition, hydraulic transients are generated by water flow and reverberations in water-filled cavities, and complex hybrid signals can be generated by brittle ice failure followed by the flow of pressurized water into fractures (St Lawrence and Qamar 1979; Walter and others, 2008; West and others, 2010). High-frequency waveforms originating from the glacier bed are characterized by impulsive P-wave onset, with most P-wave energy in the vertical axis, and no (or limited) surface wave energy; the separation of the P- and S-waves is approximately proportional to the ice thickness (Smith, 2006). Differences in the frequency, spatial distribution and timing of basal microseismic events have been used to infer glacier bed conditions in Antarctica. Anandakrishnan and Bentley (1993) detected 20 times more basal signals from the Kamb Ice Stream (KIS) than the Whillans Ice Stream (WIS). They inferred that the lower number of events detected beneath the WIS were associated with a dilatant and pervasively deforming soft bed which initiated and sustained fast ice flow, whereas the loss of till dilatancy beneath the KIS resulted in shutdown of fast flow. Basal microseismic events beneath the KIS occurred in clusters which were associated with the development of low-angle thrusts and stick-slip movements (periods of glacier acceleration followed by periods of no activity). Similarly, Smith (2006) and Smith and 


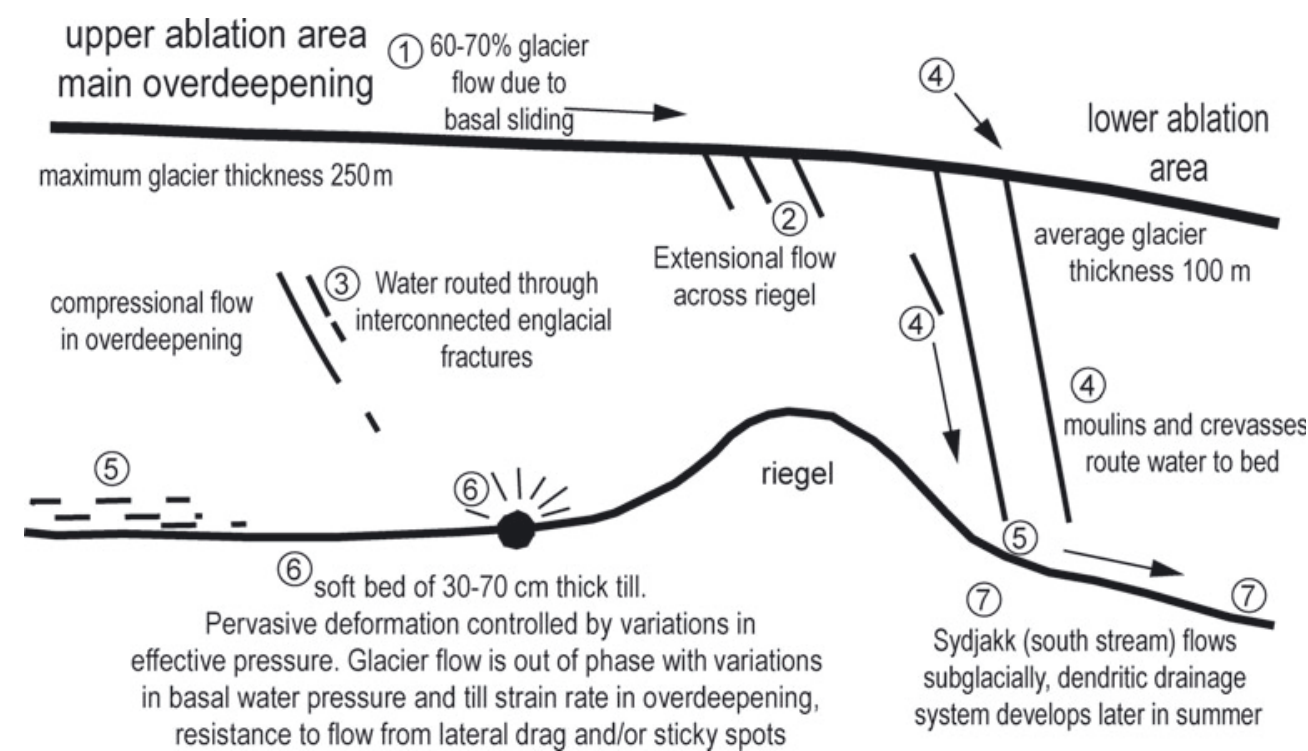

Fig. 1. Schematic representation of potential sources of microseismic signals from Storglaciären. (1) Stick-slip movements resulting in basal faulting and clusters of basal signals. Average surface velocity of glacier is $35 \mathrm{~mm} \mathrm{~d}^{-1}$, but with a maximum of up to $100 \mathrm{~mm} \mathrm{~d}^{-1}$ (Holmlund and Jansson, 2002). Glacier accelerates with extensional flow across riegel. Glacier flow rate varies over short timescales. (2) Brittle fracture related to crevassing. (3) Brittle fracture related to opening/closing of englacial fractures - possible complex hybrid waveforms. (4) Hydraulic transients related to water flow and widening of crevasses/fractures/conduits. Moulins and crevasses route water to the bed in the lower ablation area, where there are wide variations in basal water pressures. High basal water pressures decouple glacier from bed and linked to flow accelerations, but reduced shearing in tills. (5) Decoupling/recoupling of glacier to bed may generate brittle fracture and basal signals. Basal water pressures $60-80 \%$ of overburden pressure in main overdeepening, which may be a zone of low basal drag but is more variable in the lower ablation area (Holmlund and Jansson, 2002). (6) Non-uniform till deformation - release of elastic strain energy through brittle failure at sticky spots or bed relaxing in shear during decoupling. (7) Hydraulic jacking in water-filled cavities pulls the glacier forward; hydraulic jacking may produce englacial/subglacial signals and hydraulic transients. Other sources: rockfalls, serac collapse, atmospheric noise, anthropogenic noise.

Murray (2009) found that zones of fast ice flow in the Rutford Ice Stream were associated with smooth, pervasively deforming beds, and these zones produced six times fewer basal signals than rough-bedded regions where basal sliding or stick-slip movement dominated. As such, Smith (2006) argued that passive seismology could be used to map out the style of basal motion beneath glaciers.

In temperate valley glaciers, the dominance of nearsurface events associated with meltwater flow and crevassing can make basal signals difficult to distinguish (Walter and others, 2008). Also, the inability to identify events on more than one station, combined with frequent difficulties in measuring $\mathrm{P}-\mathrm{S}$ separation times where the ice is very thin, often precludes common methods of basal event location. On Gornergletscher, Swiss Alps, Walter and others (2008) found that basal waveforms were very rare $(<0.5 \%$ of all events detected) and tended to occur only in the early morning; they attributed the temporal clustering of basal signals to extensional ice fracturing caused by the glacier recoupling to its bed. Similarly, only $8 \%$ of the events detected by Stuart and others (2005) on surging Bakaninbreen, Svalbard, were interpreted as basal signals produced by brittle fracture at the glacier bed.

As part of a wider study of subglacial processes and their relation to flow dynamics in sub-arctic polythermal glaciers, we established a passive seismology experiment on Storglaciären, northern Sweden. Our aim was to catalogue and characterize microseismic events in order to better understand how these events relate to glacier flow. The particular focus was on the detection of basally derived signals that may provide evidence about glacier bed conditions and processes. Figure 1 shows how the known flow dynamics of Storglaciären may act as potential sources of microseismic signals.

\section{STUDY SITE}

Storglaciären is a small polythermal valley glacier located on the eastern side of the Kebnekaise mountains in the subarctic region of northern Sweden $\left(67^{\circ} 55^{\prime} \mathrm{N}, 18^{\circ} 35^{\prime} \mathrm{E}\right.$; Fig. 2). Storglaciären has been the focus of extensive glaciological research since 1949 and much is known about its dynamic behaviour (e.g. Jansson and Hooke, 1989; Holmlund and Jansson, 1999; Evans and others, 2008; Moore, 2009; Gusmeroli and others, 2012). It covers an area of $\sim 3 \mathrm{~km}^{2}$ and has a volume of $0.38 \mathrm{~km}^{3}, 85 \%$ of which is temperate ice (Holmlund and others, 1996). The glacier flows from a head elevation of $1730 \mathrm{~m}$ to a terminus position at $1120 \mathrm{~m}$, where the cold surface layer reaches a maximum thickness of $60 \mathrm{~m}$ (Jansson, 1995). Bedrock riegels produce four overdeepenings in the longitudinal profile of the glacier. The main overdeepening, which occurs just below the equilibrium line and where the glacier attains its maximum thickness of $\sim 250 \mathrm{~m}$, has a depth of $\sim 60 \mathrm{~m}$ (Hooke, 1989).

\section{SURVEY PROCEDURES}

In July 2010, five seismic stations were deployed in a fourpoint diamond array across the main overdeepening and set to continuously record with a sample rate of $1000 \mathrm{~Hz}$. This location was selected because: basal sliding and stickslip movements are likely in this area (Iverson and others, 1995; Fischer and others, 1996); these processes are thought to generate basal microseismic signals; and the greater 
thickness of the glacier in this area maximizes the chance of getting sufficient $\mathrm{P}$ - and S-wave separation to allow for accurate event identification and location.

Stations were separated by $\sim 200 \mathrm{~m}$, similar to the average depth of the glacier in this area (Smith, 2006), although rockfalls, crevasses, moulins and supraglacial channels constrained the locations and resulted in the array becoming somewhat elongated (Fig. 2). Each station consisted of a $4.5 \mathrm{~Hz}$ three-component geophone with pre-amplifier and oriented with north-south axis perpendicular to flow. To ensure the geophones remained stable and well coupled to the ice, they were mounted on pre-moulded concrete blocks with a flat upper surface and holes to allow the three pointed feet to pass through and be frozen into the ice below. Each geophone assembly was placed in pit dug $0.5 \mathrm{~m}$ into the ice surface. A plastic bucket was placed over each geophone and the pits back-filled with ice and covered with a rock cairn to reduce surface noise and to add protection from melt. Data were recorded by ISSI SAQS data loggers housed inside Zarges boxes. The boxes and connecting cables were also buried and protected by rock cairns. Each station was powered by a lead-acid battery (housed in the Zarges box), and two solar panels. A common time signal was derived from Garmin GPS units secured to the solar panels and connected to the loggers.

\section{DATA ANALYSIS METHODS}

The geophones remained buried, well coupled to the glacier and level on $\sim 18$ of the 29 days of the experiment, and these days yielded data of sufficient quality to allow for waveform characterization. PQL II software (McNamara and Boaz, 2011) was used to manually inspect in detail five 24 hour periods of good-quality data in order to characterize the typical and atypical waveforms present. Inspection was undertaken both with and without a $100 \mathrm{~Hz}$ high-pass filter applied. This can help distinguish high-frequency basal events from surface events which display a significant lowfrequency surface wave component (personal communication from S. Anandakrishnan, 2012). P-, S- and surface-wave arrivals were differentiated on the basis of particle motion and polarization characteristics. Waveform types were classified visually on the basis of duration, amplitude, form and steepness of onset.

To assist in the identification of events originating at the glacier bed, a model of the array was constructed based on inter-station distances and elevations, with basal events assumed directly beneath station CC at a realistic depth of $200 \mathrm{~m}$. Assuming P- and S-wave velocities of 3.6 and $1.8 \mathrm{~km} \mathrm{~s}^{-1}$ respectively (Röthlisberger, 1972), basal events would yield $\mathrm{P}-\mathrm{S}$ separation times of $0.05 \mathrm{~s}$ for station $\mathrm{CC}$ and $0.1 \mathrm{~s}$ for outlying stations.

\section{WAVEFORM CHARACTERIZATION AND INTERPRETATION}

The physical characteristics of the five main waveforms detected are described in Table 1, along with their interpretations. Examples of real events are shown in Figure 3. Different types of event were dominant at different times. This is illustrated in Table 2, which shows a comparison of the number of events of each type that occurred between 03:00 and 04:00 and between 15:00 and 16:00 on 14 July 2010.

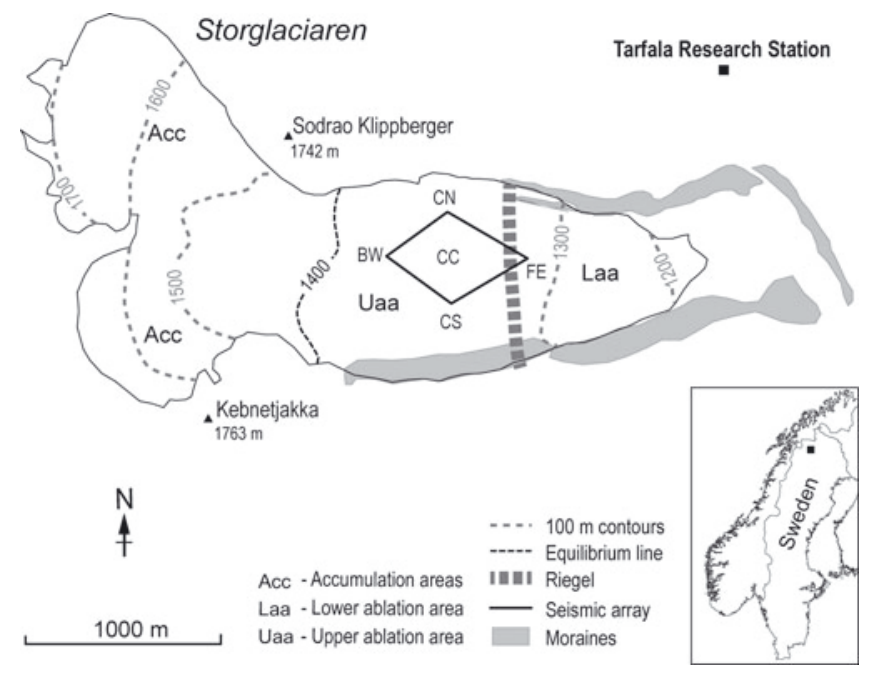

Fig. 2. Location diagram for Storglaciären and the disposition of the seismic array over the main overdeepening.

Type 1 waveforms were the most common events and were detected on all stations. Type $1 \mathrm{~b}$ and $1 \mathrm{c}$ waveforms were typically detected on either station BW or CS first, and observed to reduce rapidly in amplitude as they traversed the array. Type 1 waveforms are interpreted as surface/nearsurface events occurring at different epicentral distances across the array (Deichmann and others, 2000; Mikesell and others, 2012). They have characteristics similar to those produced by crevassing, with weak P-waves and dominant surface waves.

Due to the absence of surface waves, Type 2 waveforms resemble high-frequency intermediate or basal signals (Smith, 2006). Type 2 waveforms are rare, and seldom detected on more than two stations at once, making determination of their source location difficult. In the majority of cases, Type 2 waveforms are only weakly detected on adjacent stations or not detected at all, which suggests that the distance between the seismic source and the geophone receiver is less than the inter-station spacing (West and others, 2010), i.e. $<170 \mathrm{~m}$ for station CS which is located in an area where the depth to the bed is known to be $\sim 250 \mathrm{~m}$. Moreover, the observed $\mathrm{P}$ - and $\mathrm{S}$-wave separation time for many Type 2 waveforms is $<0.01 \mathrm{~s}$ which is far too short for basal events. The majority of Type 2 waveforms show a P-wave with sub-horizontal linear particle motion oriented perpendicular to ice flow, implying a non-vertical propagation path for P-waves. As such, we interpret Type 2 waveforms not as basal signals but as near-field events from intermediate depth (where we define 'near-field' as significantly closer to one station than any other such that for small events little or no energy can be identified above the background noise at adjacent stations).

Type 3 waveforms are episodic and high-frequency $(260 \mathrm{~Hz}$ dominant in Fig. 3e). They only occur on one or two stations simultaneously, and are most frequently detected on stations CS, CC and BW. As with Type 2 waveforms, the failure to detect Type 3 waveforms on all stations suggests that these are near-field events. The lack of, or inability to discriminate, $\mathrm{P}$ - and S-waves also suggests Type 3 waveforms are generated by near-field events. However, Type 3 waveforms lack high-amplitude surface waves and each episode has a strong and impulsive onset, which suggests these events are not formed by the surface processes 
Table 1. Typical and atypical waveforms

\begin{tabular}{|c|c|c|c|}
\hline Waveform & Type 1a & Type 1b & Type 1c \\
\hline Onset & Impulsive $\mathrm{P}$. & $\begin{array}{l}\text { Weak impulsive to } \\
\text { emergent } \mathrm{P} ; \mathrm{S} \text { difficult } \\
\text { to pick. }\end{array}$ & $\begin{array}{l}\text { Relatively weak but } \\
\text { impulsive P; S difficult } \\
\text { to pick. }\end{array}$ \\
\hline Amplitude & $\begin{array}{l}\text { Sharp peak soon after } \\
\text { onset on all channels, } \\
\text { but decays across array. }\end{array}$ & $\begin{array}{l}\text { Highest-amplitude } \\
\text { surface waves have } \\
\text { broader, higher and } \\
\text { more rounded peaks } \\
\text { than Type 1a. }\end{array}$ & $\begin{array}{c}\text { Event builds towards } \\
\text { later and more pro- } \\
\text { nounced peaks than in } \\
\text { Type } 1 \mathrm{a} \text { and Type } 1 \mathrm{~b} \text {. } \\
\text { Occasionally coda has } \\
\text { short high-frequency } \\
\text { onset and long, } \\
\text { decaying, low-frequency } \\
\text { tail. }\end{array}$ \\
\hline Spectra & $\begin{array}{l}\text { Mainly (relatively) low- } \\
\text { frequency, } 10-100 \mathrm{~Hz} \text {, } \\
\text { peaks at 10-20 and } \\
60-80 \mathrm{~Hz} \text {, small } \\
\text { component }>100 \mathrm{~Hz} \text {. }\end{array}$ & $\begin{array}{l}\text { Low-frequency } \\
10-100 \mathrm{~Hz} \text {, removed by } \\
\text { high-pass filter }(100 \mathrm{~Hz}) \\
\text { as lack higher-frequency } \\
\text { component of Type 1c } \\
\text { events. }\end{array}$ & $\begin{array}{l}\text { Wide range, with distinct } \\
\text { peaks at } 10-50 \text { and } \\
>100 \mathrm{~Hz} \text {. Some have low- } \\
\text { frequency spike at } 3 \mathrm{~Hz} \text {. }\end{array}$ \\
\hline
\end{tabular}

Duration Typically $0.5 \mathrm{~s}$, but $<1 \mathrm{~s}$
$<1 \mathrm{~s}$.

Typically $0.5 \mathrm{~s}$.
Impulsive $\mathrm{P}$ and $\mathrm{S}$.

Strong early peak,

$\mathrm{P}$-wave strongest on

Z-axis (vertical), $\mathrm{S}$ on $\mathrm{N}$ or $\mathrm{E}$ axis.

High-frequency, $>100 \mathrm{~Hz}$.

Short, <0.1 s, but 'apparent' P- and S-wave separation $<0.01$ s for many events.
Distribution Relatively common on Very common, especially Very common, especially all stations, especially during the day when recorded first on station CC, but less so than Type 1b/1c. Event moves relatively slowly across array, losing amplitude. at night. Usually hit station BW or CS first and move across array, losing amplitude in this order: (BW or CS)-CC-

$\mathrm{CN}-\mathrm{FE}$, or can be

FE-BW in direction. Surface events.
Interpretation

Type 1 waveforms, with their dominant frequencies of $10-100 \mathrm{~Hz}$, impulsive onsets, strong R-waves, weak P-waves, and durations of $<1 \mathrm{~s}$, are typical of waveforms produced by icequakes related to the opening and closing of crevasses (Neave and Savage, 1970). Hydraulic transients have been observed to produce waveforms with a frequency of $3 \mathrm{~Hz}$, but unlike Type 1c events they have harmonic tremor and a decaying sine wave associated with resonance in water-filled cavities (Stuart and others, 2005). Hybrid forms might exist. Type 1b/1c events are occasionally preceded by, or merged with, a short-duration high-frequency event. Bimodal high-frequency/low-frequency hybrid waveforms may be

produced by ice fracture followed by the flow and reverberation of pressurized water into the fracture (West and others, 2010); may be related to the formation of englacial fractures.
Rare, mostly detected in early morning 03:0005:00 local time. Single events seldom detected on more than one or two channels.

Occasionally precede Type 1c events.

Type 2 events resemble basal events. However,

$\mathrm{P}$ - and S-wave separation too short to be basal signals for many events. Weak signature on adjacent stations and polarization analysis suggests near-field origin, most likely of intermediate depth.

Type 3

Impulsive $\mathrm{P}$ but lack of $\mathrm{P}-\mathrm{S}$ separation suggests nearfield event.

Episodic event with sharp peaks; often forms cigarshaped coda.

Very high-frequency event, peaks at 150-250 and $>400 \mathrm{~Hz}$.

Typically 3-5 s, but can be up to $14 \mathrm{~s}$. Consists of multiple pulses each lasting between 0.03 and $0.06 \mathrm{~s}$, with a $0.175 \mathrm{~s}$ interval between each. Become more common towards end of July, especially at night. Less common during early July. Can get repeated episodic events with up to 13 events $\mathrm{h}^{-1}$, but typically only detected on one station.

High-frequency episodic events with impulsive onset. Particle motions of Type 3 events are indicative of a near-field origin. Origin unknown.

Table 2. Example of temporal distribution of microseismic events by type. Data are for number of events detected on three or more stations on 14 July 2010

\begin{tabular}{|c|c|c|c|c|c|c|c|c|c|c|}
\hline & \multicolumn{5}{|c|}{$03.00-04.00$} & \multicolumn{5}{|c|}{$15.00-16.00$} \\
\hline & Type 1a & Type $1 b$ & Type 1c & Type 2 & Type 3 & Type 1a & Type 1b & Type 1c & Type 2 & Type 3 \\
\hline $\mathrm{CN}$ & 2 & 0 & 0 & 0 & 0 & 2 & 1 & 18 & 0 & 0 \\
\hline CS & 8 & 5 & 4 & 1 & 0 & 3 & 2 & 31 & 1 & 2 \\
\hline BW & 2 & 58 & 20 & 0 & 0 & 0 & 3 & 1 & 0 & 0 \\
\hline $\mathrm{CC}$ & 0 & 0 & 0 & 0 & 0 & 6 & 2 & 31 & 0 & 2 \\
\hline Total $(\%)$ & 12.0 & 63.0 & 24.0 & 1.0 & 0.0 & 10.5 & 7.6 & 77.0 & 1.0 & 3.8 \\
\hline
\end{tabular}

*Type 3 events can be more common at night, with up to 13 events of $3-5 \mathrm{sh}^{-1}$ detected towards the end of July. 

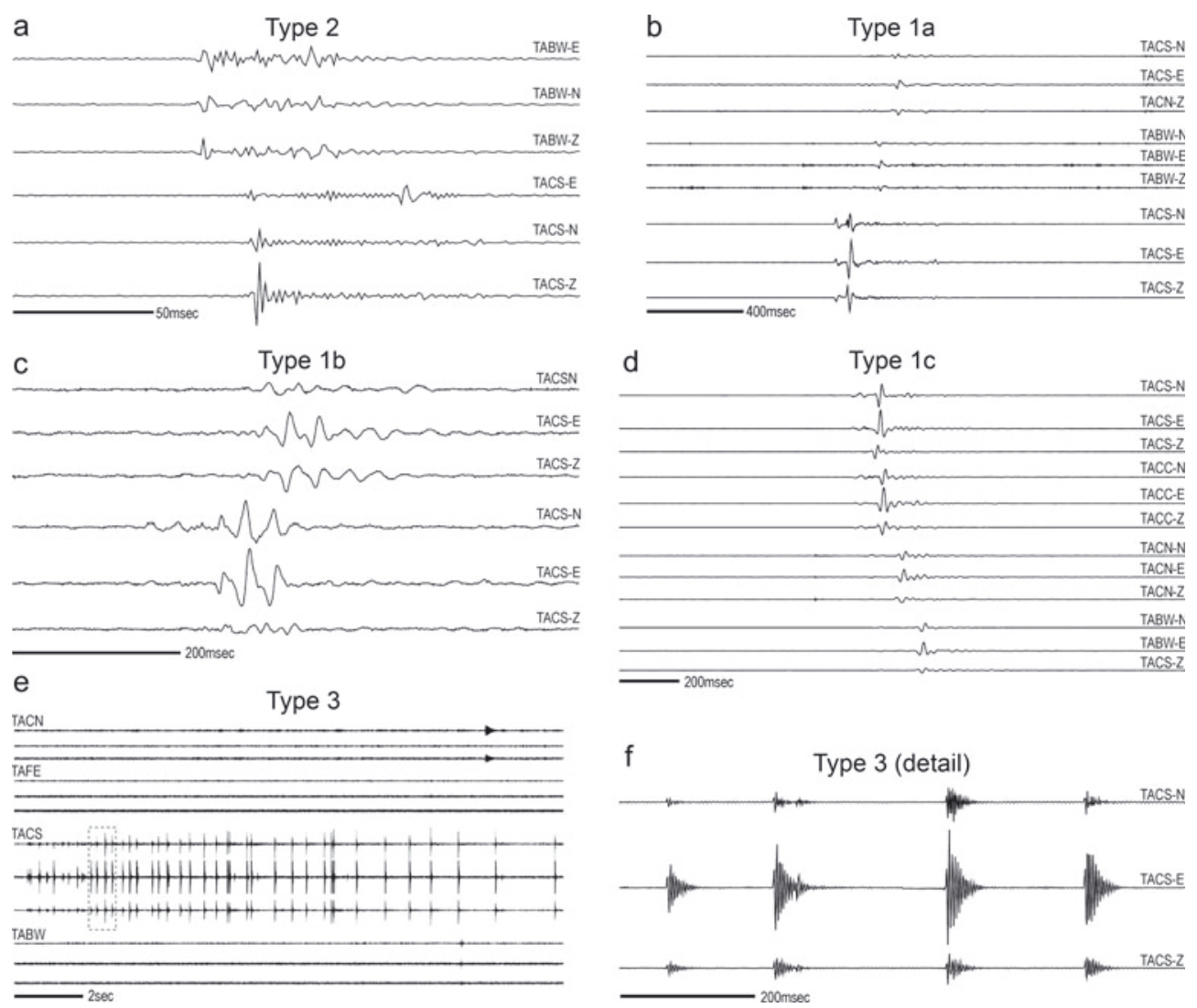

Fig. 3. Examples of waveforms detected at Storglaciären. The amplitudes of the traces are event-normalized. (a) Relatively rare Type 2 event resembling a basal signal recorded on two stations. Note the impulsive P-wave onset and high frequency $(100 \mathrm{~Hz}$ high-pass filter applied). (b) Type 1a event detected first on station CS with impulsive onset and rapidly decaying in amplitude across the array. (c) Type $1 \mathrm{~b}$ event. Note the weak P-wave onset and strong high-amplitude surface wave arrivals. Type $1 \mathrm{~b}$ events are largely removed by a $100 \mathrm{~Hz}$ high-pass filter. (d) Type 1c event. Note the weak P-wave onset. Type 1c events contain a significant higher-frequency component which is not removed by a $100 \mathrm{~Hz}$ high-pass filter and builds to a later and higher peak than Type 1a events. (e) Type 3 event recorded on one station. Episodic Type 3 events can last for up to $14 \mathrm{~s}$. Dashed box indicates location of (f). (f) Detail of Type 3 events showing high frequency and impulsive onset.

related to crevassing that generate Type 1 waveforms. The origin of Type 3 waveforms requires further investigation.

West and others (2010) identified a hybrid waveform on Bering Glacier, Alaska, USA, having impulsive highfrequency onset followed by a slow decaying low-frequency tail. The hybrid waveform was interpreted as the product of brittle ice fracture followed by the flow of pressurized water into the fracture and reverberation. Englacial fracturing in the overdeepening of Storglaciären may generate similar hybrid signals. Occasionally, Type 1 waveforms are immediately preceded by high-frequency events (often similar to Type 2 waveforms) and it is possible that this is a high-frequency/ low-frequency hybrid waveform (Fig. 3). One other possible explanation is the excitation of the spurious modes of resonance of the geophones due to adverse tilt (Faber and Maxwell, 1997). However, the specified first spurious resonant frequency of the I/O SM6 $4.5 \mathrm{~Hz}$ geophone is $140 \mathrm{~Hz}$, significantly different to that observed here.

\section{DISCUSSION}

\section{Basal signals}

Borehole experiments suggest that Storglaciären's flow dynamics are dominated by basal sliding, and that stickslip motion and sticky spots occur (Iverson and others, 1995;
Fischer and others, 1996). As such, it is surprising that no clear basal signals have been detected. We propose three hypotheses for the failure to detect basal signals.

\section{Hypothesis 1: pervasive soft-bed deformation is widespread throughout the ablation area and generates few basal signals}

Fast glacier flow associated with pervasive soft-bed deformation generates few basal signals in Antarctic ice streams (Smith, 2006), although some basal signals are detected. A dilatant till that is pervasively deforming reduces friction and causes little basal fracturing within the ice, and so generates little seismic activity. Although soft-bed deformation has been observed in the upper ablation area (Uaa) and lower ablation area (Laa) of Storglaciären (Iverson and others, 1992), basal sliding is thought to be the more important control of flow dynamics because the till is not deforming uniformly and the depth of deformation is limited to $\sim 35 \mathrm{~cm}$ (Iverson and others, 1995; Fischer and others, 1996). The presence of regelation ice in the basal ice facies at the contemporary glacier margin, and lodged stoss and lee boulders with flow-parallel striations in proglacial exposures of subglacial till (personal communication from S. Cook, 2012), demonstrate that basal sliding has been an important component of Storglaciären's recent flow dynamics. Moreover, the clast-rich and coarse-grained subglacial till which 
is now exposed on the forefield reveals strong flow-parallel clast fabrics indicative of strong glacier-bed coupling, and shows evidence of grain bridging, clast crushing and clast/ boulder lodgement, which suggests that at least part of the glacier's basal shear stress has previously been taken up by clast-rich and boulder-rich sticky spots. We suggest a similar mosaic of sticky and deforming spots exists beneath the present glacier, because till strain rates vary with changes in effective pressure, which are controlled by local variations in basal water pressure (Iverson and others, 1995). As such, pervasive soft-bed deformation is unlikely to be uniform or continuous throughout the ablation area and cannot be used by itself to explain the absence of basal signals.

\section{Hypothesis 2: basal sliding does not generate basal signals in temperate ice}

Basal sliding accounts for $60-70 \%$ of the surface velocity of polythermal Storglaciären (Jansson, 1995) and yet no basal signals have been detected. Likewise, Walter and others (2008) found no link between basal sliding and the generation of basal signals in warm-based Gornergletscher, Switzerland. The subglacial environment of Storglaciären's Uaa consists of temperate ice and is characterized by consistently high basal water pressures which probably produce a zone of low basal drag (Holmlund and Jansson, 2002). Few basal ice fractures or sticky spots are likely to develop in a zone of low basal drag, especially if temperate ice deforms plastically around bed asperities, and this may help to explain the absence of basal signals in the Uaa. Stuart and others (2005) also found a region where no basal signals were detected up-glacier of the surging wave front on polythermal Bakaninbreen, Svalbard, which they attributed to plastic failure in a zone of temperate ice.

However, basal water pressures and basal drag are more variable in Storglaciären's Laa and this gives the potential for basal signals to be generated by various mechanisms. High basal water pressures are thought to periodically and locally decouple the glacier from its bed in the Laa, which leads to flow accelerations through basal slip, with resistance to flow being taken up by sticky spots or lateral drag (Iverson and others, 1995). Flow accelerations also occur in the Uaa but are out of phase with variations in basal water pressure (Jansson, 1995; Fischer and others, 1996). Although high basal water pressures reduce effective pressure, till strain rates reduce to a minimum during glacier-bed decoupling and basal signals could be generated as the soft bed relaxes elastically in shear (Fischer and Clarke, 2001). Furthermore, Walter and others (2008) demonstrated that extensional fractures occur in temperate basal ice when a glacier recouples to its bed as basal water pressures fall, and this process produces clusters of basal signals. If this is correct, then recoupling processes should periodically generate basal signals in the Laa as basal water pressures fall. Theoretically, basal signals are also likely to be produced at sticky spots throughout the ablation area where patches of cold-based ice or stiff till fracture. As such, it is surprising that no basal signals have been detected, especially on station FE which straddles the Uaa/Laa boundary.

Hypothesis 3: basal signals are rare and difficult to detect in temperate glaciers or polythermal glaciers that largely consist of temperate ice

We suggest that this is the most likely reason for failing to detect basal signals for three reasons:
1. Low signal-to-noise ratio. Various processes, such as supraglacial and englacial water flow, help to generate a noisy environment on valley glaciers, especially during the day, and even after filtering this can make it difficult to recognize unique events and to accurately pick $\mathrm{P}$ - and $S$-wave arrival times on seismic traces. By contrast, seismic datasets from the Antarctic ice streams are characterized by low ambient noise levels.

2. High-frequency basal events are swamped by the thousands of near-field, long-period and high-amplitude surface events that occur every day. Now that waveform characterization is complete, future investigations will focus on whether it is possible to use known surface events to run a null-based cross-correlation that removes any matching waveforms from the dataset, and which leaves behind only the anomalous and non-surface waveforms.

3. Body waves are of significantly lower amplitude than surface waves for a given epicentral distance due to both greater attenuation of the higher-frequency content and spherical rather than cylindrical geometrical spreading losses. Also, at a glacier's surface, high-frequency waveforms can be preferentially attenuated by dense networks of crevasses (Walter and others, 2008). High-frequency basal signals may also be attenuated by a dense system of water-filled englacial fractures. It is known that water is mainly routed through the main overdeepening of Storglaciären via an interconnected system of englacial fractures which typically have openings $40 \mathrm{~mm}$ wide and dip at $70^{\circ}$, and which have been observed to extend to $131 \mathrm{~m}$ depth (Fountain and others, 2005). Some fractures are water-filled, although water flows slowly through them, and may drain to the bed. The origin of the fractures is unknown, but the lack of basal signals suggests they are probably not formed by basal crevassing. The fractures may be formed in situ by extensional flow through the overdeepening or by hydrofracturing. It is possible that bimodal high-frequency/low-frequency hybrid waveforms could be generated by the opening of englacial fractures and the subsequent flow of water into the fracture, and this requires further investigation.

\section{Practical data-collection issues encountered, and associated recommendations}

The high ablation rate on Storglaciären caused problems throughout the experiment. Air temperatures near the array reached $9.8^{\circ} \mathrm{C}$ at $1382 \mathrm{~m}$ altitude by late July, with melt of up to $10 \mathrm{~cm} \mathrm{~d}^{-1}$ (personal communication from T. Matthews, 2011). Initial deployment of the seismic array was delayed because meltwater could not penetrate the impermeable cold ice surface layer, resulting in pools forming on the glacier surface and in the pits dug for the geophones. As the melt season progressed, the glacier drainage system became more organized and sufficient surface meltwater was evacuated to allow the stations to be established.

The high ablation rate, combined with several severe storms with wind speeds in excess of $35 \mathrm{~m} \mathrm{~s}^{-1}$, meant that each seismic station had to be redeployed at the same site on four separate occasions because cairns had collapsed and cables and geophones had become exposed, or the geophones were so badly tilted they required re-levelling. Our experience is that each station requires monitoring on an almost daily basis to combat these issues and maximize 
the duration over which quality data are obtained. The frequency of redeployment could be reduced by action to minimize the melt rate around each station. One possibility would be to paint or coat equipment with a high-albedo material, or geotextile covers could be used to cover equipment and blanket the surface around each station. Geotextile covers such as IceProtector 500 and Toptex 350 have been shown to reduce snowmelt by up to $65 \%$ in alpine and arctic regions (Olefs and Fischer, 2008; Pomeroy, 2009). An alternative approach would be to deploy the array in autumn, allowing the geophones to freeze in, and recover it in spring. Basal sliding is thought to occur all year long on Storglaciären, although the glacier is less dynamically active when basal water pressures are reduced (Holmlund and Jansson, 2002), and the reduction in noise from flowing water might afford a better chance of detecting basal signals. However, winter conditions place restrictions on the use of solar panels, so alternative power sources would be required.

Achieving and maintaining a good coupling between the geophone and an uneven glacier ice surface at the base of an excavated pit proved to be problematic. The threecomponent geophones must be kept approximately level to maximize data quality. Our method of inserting a premoulded concrete block at the base of each pit provided a good solution. The use of concrete blocks helped to keep the geophones level, correctly orientated, and provided a good geophone-glacier coupling.

\section{CONCLUSION}

Passive seismology experiments are rendered difficult on glaciers with high surface ablation rates, and careful station design is required to mitigate the effects. Protecting stations with geotextile covers is one possibility. The data from Storglaciären are consistent with those collected on temperate glaciers, in that basal microseismic signals are rare/ absent and/or difficult to detect. The reasons for this are uncertain, but we hypothesize that it may result from: (a) consistently high basal water pressures in Storglaciären's upper ablation area creating a zone of low basal drag which, combined with soft-bed deformation, may create conditions where few basal signals are generated; (b) the plastic deformation associated with temperate ice failing to generate microseismic signals, despite the major contribution of basal sliding to glacier flow; (c) basal signals being difficult to detect on glaciers consisting of mainly temperate ice because they are drowned out by other signals or preferentially attenuated by a dense network of water-filled englacial fractures. Although we have failed to recognize microseismic evidence of glacier sliding, the nature and significance of the other signals detected will be the focus of future work.

\section{ACKNOWLEDGEMENTS}

This research was supported by a British Society for Geomorphology Research Fund Award and an equipment Ioan from the UK Natural Environment Research Council (NERC)'s Geophysical Equipment Facility (GEF Loan 925). We thank Tom Matthews and staff at the Tarfala Research Station for field assistance. We also thank Andy Smith and two anonymous reviewers whose comments helped us to improve the manuscript.

\section{REFERENCES}

Alley RB, Blankenship DD, Bentley CR and Rooney ST (1987) Continuous till deformation beneath ice sheets. IAHS Publ. 170 (Symposium at Vancouver 1987 - The Physical Basis of Ice Sheet Modelling), 81-91

Anandakrishnan S and Bentley CR (1993) Micro-earthquakes beneath Ice Streams B and C, West Antarctica: observations and implications. J. Glaciol., 39(133), 455-462

Blankenship DD, Bentley CR, Rooney ST and Alley RB (1986) Seismic measurements reveal a saturated porous layer beneath an active Antarctic ice stream. Nature, 322(6074), 54-57 (doi: $10.1038 / 322054 a 0)$

Boulton GS and Hagdorn M (2006) Glaciology of the British Isles Ice Sheet during the last glacial cycle: form, flow, streams and lobes. Quat. Sci. Rev., 25(23-24), 3359-3390 (doi: 10.1016/ j.quascirev.2006.10.013)

Boulton GS and Hindmarsh RCA (1987) Sediment deformation beneath glaciers: rheology and geological consequences. J. Geophys. Res., 92(B9), 9059-9082 (doi: 10.1029/ JB092iB09p09059)

Boulton GS, Dobbie KE and Zatsepin S (2001) Sediment deformation beneath glaciers and its coupling to the subglacial hydraulic system. Quat. Int., 86(1), 3-28 (doi: 10.1016/S10406182(01)00048-9)

Carr SJ (2004) Microscale features and structures. In Evans DJA and Benn DI eds. A practical guide to the study of glacial sediments. Hodder Education, London, 115-144

Clark PU (1994) Unstable behavior of the Laurentide ice sheet over deforming sediment and its implications for climate change. Quat. Res., 41(1), 19-25 (doi: 10.1006/qres.1994.1002)

Clarke GKC (2005) Subglacial processes. Annu. Rev. Earth Planet. Sci., 33, 247-276 (doi: 10.1146/annurev.earth.33.092203. 122621)

Deichmann N, Ansorge J, Scherbaum F, Aschwanden A, Bernardi F and Gudmundsson GH (2000) Evidence for deep icequakes in an Alpine glacier. Ann. Glaciol., 31, 85-90 (doi: 10.3189/ 172756400781820462)

Evans E, Essery R and Lucas R (2008) Changing snow cover and the net mass balance of Storglaciären, northern Sweden. Ann. Glaciol., 49, 199-204 (doi: 10.3189/172756408787814933)

Faber K and Maxwell PW (1997) Geophone spurious frequency: what is it and how does it affect seismic data quality? Can. J. Explor. Geophys., 33(1-2), 46-54

Fischer UH and Clarke GKC (2001) Review of subglacial hydromechanical coupling: Trapridge Glacier, Yukon Territory, Canada. Quat. Int., 86(1), 29-43 (doi: 10.1016/S1040-6182(01) 00049-0)

Fisher U, Grace E, Hanson B, Hooke RLeB and Jansson P (1996) Basal till rheology studies on Storglaciären. In Jansson P ed. Tarfala Research Station Annual Report 1994-5. Stockholm University, Stockholm

Fountain AG, Jacobel RW, Schlichting R and Jansson P (2005) Fractures as the main pathways of water flow in temperate glaciers. Nature, 433(7026), 618-621 (doi: 10.1038/nature03296)

Gusmeroli A, Jansson P, Pettersson R and Murray T (2012) Twenty years of cold surface layer thinning at Storglaciären, sub-Arctic Sweden, 1989-2009. J. Glaciol., 58(207), 3-10 (doi: 10.3189/ 2012JoG11J018)

Holmlund $\mathrm{P}$ and Jansson $\mathrm{P}$ (1999) The Tarfala mass balance programme. Geogr. Ann. A, 81(4), 621-631 (doi: 10.1111/ j.0435-3676.1999.00090.x)

Holmlund P and Jansson P (2002) Glaciological research at Tarfala Research Station. Stockholm University, Stockholm

Holmlund P, Karlén W and Grudd H (1996) Fifty years of mass balance and glacier front observations at the Tarfala Research Station. Geogr. Ann. A, 78(2-3), 105-114

Hooke RLeB (1989) Water flow through a glacier situated in an overdeepening: cause or consequence of a till layer at the bed. Ann. Glaciol., 12, 213 
Iverson NR, Jansson P, Hooke RLeB and Hanson B (1992) Direct measurement of the shear strength and deformation of till beneath Storglaciären, N. Sweden. Eos, 73(43), Fall Meet. Suppl., 160

Iverson NR, Hanson B, Hooke RLeB and Jansson P (1995) Flow mechanism of glaciers on soft beds. Science, 267(5194), 80-81 (doi: 10.1126/science.267.5194.80)

Jansson P (1995) Water pressure and basal sliding on Storglaciären, northern Sweden. J. Glaciol., 41(138), 232-240

Jansson P and Hooke RLeB (1989) Short-term variations in strain and surface tilt on Storglaciären, Kebnekaise, northern Sweden. J. Glaciol., 35(120), 201-208

MacAyeal DR (1993) Binge/purge oscillations of the Laurentide ice sheet as a cause of the North Atlantic's Heinrich events. Paleoceanography, 8(6), 775-784 (doi: 10.1029/93PA02200)

McNamara DE and Boaz RI (2011) PQLX: a seismic data quality control system description, applications, and user's manual. USGS Open File Rep. 2010-1292

Mikesell TD, Van Wijk K, Haney MM, Bradford JH, Marshall HP and Harper JT (2012) Monitoring glacier surface seismicity in time and space using Rayleigh waves. J. Geophys. Res., 117(F2), F02020 (doi: 10.1029/2011JF002259)

Moore PL (2009) Dynamics of ice flow and sediment transport at a polythermal glacier terminus: Storglaciären, Sweden. (PhD thesis, lowa State University)

Neave KG and Savage JC (1970) Icequakes on the Athabasca Glacier. J. Geophys. Res., 75(8), 1351-1362 (doi: 10.1029/ JB075i008p01351)

Olefs M and Fischer A (2008) Comparative study of technical measures to reduce snow and ice ablation in Alpine glacier ski resorts. Cold Reg. Sci. Technol., 52(3), 371-384 (doi: 10.1016/ j.coldregions.2007.04.021)

Passchier S, Laban C, Mesdag CS and Rijsdijk KF (2010) Subglacial bed conditions during Late Pleistocene glaciations and their impact on ice dynamics in the southern North Sea. Boreas, 39(3), 633-647 (doi: 10.1111/j.1502-3885.2009.00138.x)

Piotrowski JA, Mickelson DM, Tulaczyk S, Krzyszkowski D and Junge FW (2001) Were deforming subglacial beds beneath past ice sheets really widespread? Quat. Int., 86(1), 139-150 (doi: 10.1016/S1040-6182(01)00056-8)

Piotrowski JA, Larsen NK and Junge FW (2004) Reflections on soft subglacial beds as a mosaic of deforming and stable spots.
Quat. Sci. Rev., 23(9-10), 993-1000 (doi: 10.1016/j.quascirev. 2004.01.006)

Pomeroy JA (2009) The effectiveness of geotextile covers in reducing snowmelt in an ephemeral Scottish snowpack and a high arctic snowpack - an empirical study. (MSc thesis, University of Sheffield)

Röthlisberger H (1972) Seismic exploration in cold regions. CRREL Monogr. II-A2a

Roux P-F, Marsan D, Metaxian J-P, O'Brien G and Moreau L (2008) Microseismic activity within a serac zone in an alpine glacier (Glacier d'Argentière, Mont Blanc, France). J. Glaciol., 54(184), 157-168 (doi: 10.3189/002214308784409053)

Smith AM (2006) Microearthquakes and subglacial conditions. Geophys. Res. Lett., 33(24), L24501 (doi: 10.1029/ 2006GL028207)

Smith AM and Murray T (2009) Bedform topography and basal conditions beneath a fast-flowing West Antarctic ice stream. Quat. Sci. Rev., 28(7-8), 584-596 (doi: 10.1016/j.quascirev.2008.05.010)

Solomon S and 7 others eds. (2007) Climate change 2007: the physical science basis. Contribution of Working Group I to the Fourth Assessment Report of the Intergovernmental Panel on Climate Change. Cambridge University Press, Cambridge

St Lawrence W and Qamar A (1979) Hydraulic transients: a seismic source in volcanoes and glaciers. Science, 203(4381), 654-656 (doi: 10.1126/science.203.4381.654)

Stuart G, Murray T, Brisbourne A, Styles P and Toon S (2005) Seismic emissions from a surging glacier: Bakaninbreen, Svalbard. Ann. Glaciol., 42, 151-157 (doi: 10.3189/ 172756405781812538)

Thomason JF and Iverson NR (2009) Deformation of the Batestown till of the Lake Michigan Lobe, Laurentide ice sheet. J. Glaciol., 55(189), 131-146 (doi: 10.3189/ 002214309788608877)

Walter F, Deichmann N and Funk M (2008) Basal icequakes during changing subglacial water pressures beneath Gornergletscher, Switzerland. J. Glaciol., 54(186), 511-521 (doi: 10.3189/ 002214308785837110)

West ME, Larsen CF, Truffer M, O'Neel S and LeBlanc L (2010) Glacier microseismicity. Geology, 38(4), 319-322 (doi: 10.1130/G30606.1) 